Open Access

\title{
Effect of filler addition on solidification behaviour and hot tensile properties of GTA-welded tube joints of Super $304 \mathrm{H}$ austenitic stainless steel
}

\author{
M. Vinoth Kumar ${ }^{1}$, V. Balasubramanian ${ }^{1 *}$ and A. Gourav Rao ${ }^{2}$
}

\begin{abstract}
Background: Super 304H austenitic stainless steel tubes containing 2.3 to 3 (wt.\%) of Cu are mainly used in superheaters and reheaters of ultra super critical boilers due their excellent corrosion and oxidation resistance. $\mathrm{Cu}$ addition causes precipitation strengthening effect by fine Cu-rich precipitates which evolve during creep conditions and results in increased creep strength. The microstructural evolution of stainless steels during welding significantly affects the material properties.
\end{abstract}

Methods: In this work, solidification mode microstructure and hot tensile properties of autogenous and filler-added Super $304 \mathrm{H}$ gas tungsten arc (GTA) welded tube joints were correlated.

Results: Autogenous welds of Super $304 \mathrm{H}$ solidified as austenite with $1.57 \%$ delta ferrite and intercellular $(\mathrm{Fe}, \mathrm{Cr})_{23}(\mathrm{C}, \mathrm{B})_{6}$ borocarbides. In filler-added welds, the higher $\mathrm{Ni}$ equivalent and addition of carbide stabilizing elements $(\mathrm{Nb}, \mathrm{Mo})$ eliminated $\delta$ ferrite and segregation of $\mathrm{B}$ as borocarbides.

Conclusions: The filler-added welds exhibited superior tensile strength than autogenous welds at both room and high temperature.

Keywords: Super 304H, Gas tungsten arc welding, Solidification behaviour, Segregation, Hot tensile properties

\section{Background}

Efficiency of the power plant strongly depends on the operating steam temperature and pressure. The concern for reducing the $\mathrm{CO}_{2}$ emission and coal consumption leads to the efforts to build power plants operating at higher steam parameters (Brozda 2007; Shu Ping et al. 2010; David et al. 2013). Austenitic stainless steels are selected for use in sections of superheaters and reheaters, which require good oxidation and fire side corrosion resistance, in addition to the creep strength. The recent improvements in operating steam temperatures up to $620^{\circ} \mathrm{C}$ were achieved through the development of creep-resistant stainless steels, containing $\mathrm{Cr}, \mathrm{Ni}, \mathrm{W}, \mathrm{Co}$,

\footnotetext{
* Correspondence: visvabalu@yahoo.com

'Center for Materials Joining and Research (CEMAJOR), Department of Manufacturing Engineering, Annamalai University, Annamalai Nagar, Tamil Nadu 608002, India

Full list of author information is available at the end of the article
}

$\mathrm{Cu}$ and $\mathrm{N}$. Future plans of increasing the efficiency of the power plants up to $49 \%$ require creep-resistant steels operating at steam temperatures of $760{ }^{\circ} \mathrm{C}$ and pressures of $35 \mathrm{MPa}$ (Viswanathan et al. 2005). Super $304 \mathrm{H}$ austenitic stainless steel is used in recently installed ultra super critical (USC) power units of Japan operating at steam temperature of about $613{ }^{\circ} \mathrm{C}$ (Thomas 2013). Further, Super $304 \mathrm{H}$ is listed as a candidate material for superheaters and reheaters in the US program for development of materials for USC with steam temperatures of $760{ }^{\circ} \mathrm{C}$ (Viswanathan et al. 2005). Super $304 \mathrm{H}$ with nominal composition of $0.1 \mathrm{C}-18 \mathrm{Cr}-9 \mathrm{Ni}-3 \mathrm{Cu}-\mathrm{Nb}-\mathrm{N}$ derives excellent creep strength from the distinct $\mathrm{Cu}$ addition which precipitates as fine $\mathrm{Cu}$-rich particle under creep conditions, in addition to $\mathrm{NbCrN}, \mathrm{Nb}(\mathrm{C}, \mathrm{N})$ and $\mathrm{M}_{23} \mathrm{C}_{6}$ particles (Li et al. 2010).

The different modes of solidification mechanism (A-AF-FA-F) and the methods to predict the volume 
Table 1 Chemical composition (wt.\%) of parent metal (PM) and filler metal (FM)

\begin{tabular}{|c|c|c|c|c|c|c|c|c|c|c|c|c|c|}
\hline & C & $\mathrm{Si}$ & $\mathrm{Mn}$ & $P$ & $S$ & $\mathrm{Cr}$ & $\mathrm{Ni}$ & $N$ & $\mathrm{Cu}$ & $\mathrm{Nb}$ & Mo & $B$ & $\mathrm{Al}$ \\
\hline PM & 0.086 & 0.23 & 0.81 & 0.021 & 0.0003 & 18.18 & 9.06 & 0.095 & 3.080 & 0.045 & - & 0.0039 & 0.01 \\
\hline FM & 0.1 & 0.3 & 3.3 & $<0.01$ & $<0.01$ & 18.3 & 15.7 & 0.16 & 2.9 & 0.5 & 0.7 & - & - \\
\hline
\end{tabular}

percentage of ferrite along with the solidification modes are described in detail elsewhere (Valiente Bermejo 2012). A ternary alloy with a composition of Super 304H is expected to solidify as austenite under equilibrium conditions (Hunter and Ferry 2002). In non-equilibrium cooling conditions such as welding, the solidification sequence of the stainless steel depends on the cooling rate and, in highly alloyed steels such as Super $304 \mathrm{H}$, it may result in local compositional variation due to segregation, which alters the solidified phases at room temperature (Darja Steiner et al. 2011).

Recently, few investigations (Indrani et al. 2011; Yang et al. 2006; Li et al. 2010; Bai et al. 2013; Ha and Jung 2012) were carried out to understand the ageing behaviour of Super 304H alloy at high temperatures and evaluated the effect of varying $\mathrm{Cu}$ content on microstructure and mechanical properties of the alloy. Works carried out on weldability studies and high temperature properties of Super $304 \mathrm{H}$ weld joints reported the tendency of Super $304 \mathrm{H}$ to hot cracking and use of matching Super $304 \mathrm{H}$ filler metal as an alternate to Ni-based filler metal (Vekeman et al. 2014; Kim et al. 2014). However, the available information on solidification behaviour of gas tungsten arc (GTA) welds of Super $304 \mathrm{H}$ and its effects on high temperature properties are very scant. Hence in this work, an attempt has been made to compare the solidification modes, microstructure and hot tensile properties of autogenous and filler-added GTA-welded tube joints of Super $304 \mathrm{H}$ austenitic stainless steel. The amount of alloy segregation, composition of segregated elements in autogenous joints, and the role of alloying elements added in the filler metal to avoid detrimental segregation along with their effects on tensile strength of the joints are discussed in this paper.

\section{Methods}

Super $304 \mathrm{H}$ austenitic stainless steel tubes of outer diameter $57.1 \mathrm{~mm}$ and wall thickness of $3.5 \mathrm{~mm}$ were used in this investigation. Chemical composition of the

Table 2 Tensile properties of parent metal in as-received condition

\begin{tabular}{lllll}
\hline & $\begin{array}{l}0.2 \% \text { yield } \\
\text { strength (MPa) }\end{array}$ & $\begin{array}{l}\text { Ultimate tensile } \\
\text { strength (MPa) }\end{array}$ & $\begin{array}{l}\text { Elongation in } \\
25 \mathrm{~mm} \text { gauge } \\
\text { length (\%) }\end{array}$ & $\begin{array}{l}\text { Annealing } \\
\text { temperature }\end{array}$ \\
\hline $\begin{array}{l}\text { Parent } \\
\text { material }\end{array}$ & 284.2 & 575.8 & 71.8 & $1145^{\circ} \mathrm{C}$ \\
\hline
\end{tabular}

Super $304 \mathrm{H}$ tube and filler metal used in this investigation are presented in Table 1. The tensile properties of tube in solution-annealed condition are given in Table 2. For autogenous welds, the joints with square butt preparation with no gap was employed, and for filler-added welds, the joints with single ' $\mathrm{V}$ ' butt preparation was welded using GTAW process. Argon was used as the shielding and purging gas for both cases, with flow rates of 12 and $10 \mathrm{~L} / \mathrm{min}$, respectively. The welding parameters used in this investigation are shown in Table 3.

Photographs of the autogenous and filler-added GTAweld joints are shown in Fig. 1a, b, respectively. To identify the mode of weld solidification, microstructural examinations were carried out by obtaining samples from the weld joints. The samples were prepared using standard metallographic techniques and etched with Glyceregia for 5-10 s to reveal the general structure and with boiling Murakami's reagent to reveal $\delta$ ferrite and carbides. The microstructural examination of the samples was carried out using light optical microscope (OM) with image analysing software, field emission scanning electron microscope (FE-SEM). The compositional variation within the weld regions was analysed using energydispersive spectroscopy (EDS) attached with SEM. The $\delta$ ferrite measurement in the welds was carried out using ferritescope. The specimens for transverse tensile test were extracted from the weld joints using wire-cut electric discharge machining. Figure $1 \mathrm{c}$ represents the dimension of the transverse tensile specimens extracted from the weld joints. Instron universal testing machine (UTM) was used to carry out the tensile testing, under constant crosshead speed mode with a nominal strain rate of $1 \times 10^{-3} \mathrm{~S}^{-1}$. The tensile tests were carried out at four different test temperatures (room temperature (RT), $550{ }^{\circ} \mathrm{C}, 600{ }^{\circ} \mathrm{C}$ and $650{ }^{\circ} \mathrm{C}$ ). The UTM system was equipped with a three-zone resistance heating furnace for high temperature tests and a computer with data acquisition system for obtaining digital load-elongation data. The photograph of hot tensile test specimens after

Table 3 Parameters for GTAW welding of Super 304H

\begin{tabular}{lll}
\hline $\begin{array}{l}\text { Mode of welding } \\
\text { Power source type }\end{array}$ & $\begin{array}{l}\text { Autogenous welding } \\
\text { Constant current }\end{array}$ & $\begin{array}{l}\text { With filler addition } \\
\text { Constant current }\end{array}$ \\
\hline Current $(A)$ & 100 & 75 \\
Voltage $(\mathrm{V})$ & 11 & 11.3 \\
Welding speed $(\mathrm{mm} / \mathrm{min})$ & 70 & 75 \\
Heat input $(\mathrm{kJ} / \mathrm{mm})$ & 0.943 & 0.68 \\
\hline
\end{tabular}




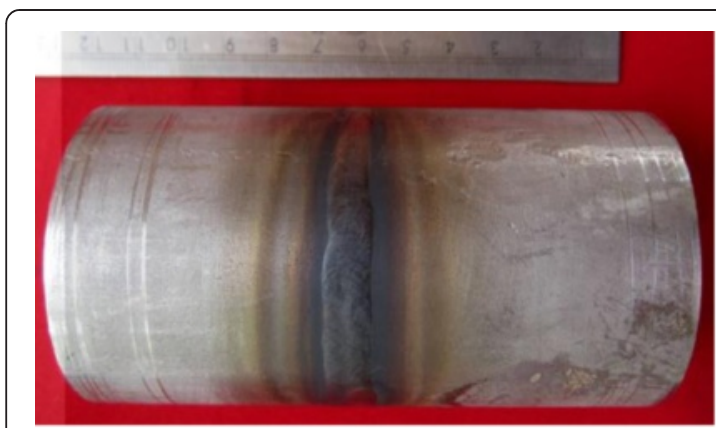

a. Autogenously welded tube joint

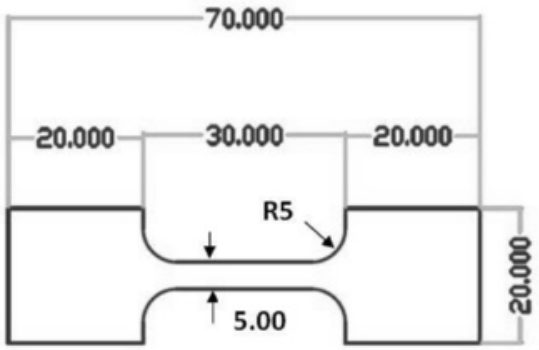

c. Dimensions of hot tensile specimen in ' $\mathrm{mm}$ '

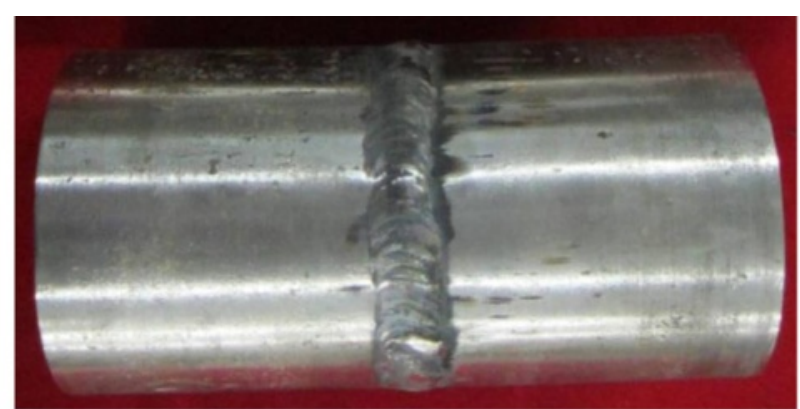

b. Welded tube joint with filler addition

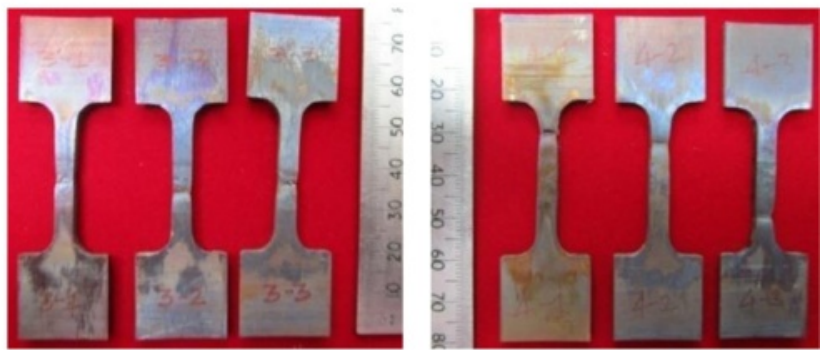

Autogenous joints Filler added joints

d. Hot tensile specimens after test

Fig. 1 Photographs of welded tubes and details of tensile specimens. a Autogenously welded tube joint. b Welded tube joint with filler addition. c Dimensions of hot tensile specimen in ' $m m^{\prime}$ '. $\mathbf{d}$ Hot tensile specimens after test

the test is shown in Fig. 1d. The hardness was measured across the weld centre line using Vickers microhardness tester with a load of $500 \mathrm{~g}$ and dwell time of $15 \mathrm{~s}$. The fracture surfaces of the tensile specimens were analysed using SEM to reveal the mode of fracture.

\section{Results}

\section{Microstructure}

Figure 2a shows the macrograph of the autogenous GTAW joint and it reveals the various regions of the joint, consisting of parent metal (PM), heat-affected zone (HAZ) and fusion zone (FZ). Figure $2 \mathrm{~b}$ shows the microstructural variation across the joint at low magnification. The micrograph of weld metal (WM) is shown in Fig. 2c, which reveals the presence of austenite (white phase) with $\delta$ ferrite (dark phase). Micrograph of the WM at centre of the joint, shown in Fig. 2d, reveals the presence of precipitates both within the austenite grains and in the austenitic grain boundaries. The presence of precipitates within the $\delta$ ferrite at the grain boundaries was also revealed in Fig. 2d. Micrograph of weld fusion line shown in Fig. 2e reveals the presence of $\delta$ ferrite with mixed morphology and preferential orientation towards the weld centre.

Macrograph of the filler-added GTAW joint is shown in Fig. 3a and the microstructural variation across the joint is shown in Fig. 3b. The WM micrograph of the filler-added weld joint, shown in Fig. 3c, reveals the presence of fully austenitic equiaxed dendritic structure.
The grain size of the filler-added WM is coarser (80$100 \mu \mathrm{m})$ than the PM $(30-40 \mu \mathrm{m})$. Micrograph of filleradded WM is shown at higher magnification in Fig. 3d and reveals no $\delta$ ferrite. However, it consists of finer interdendritic and grain boundary precipitates than the autogenous weld. The fusion line of filler-added joint is shown in Fig. 3e, which reveals the partially melted zone with epitaxial growth of austenitic grains towards the weld centre with no evidence of $\delta$ ferrite.

SEM micrograph of HAZ of the autogenous weld joint is shown in Fig. 4a, and it reveals coarsening of precipitates and austenite grains. Figure $4 \mathrm{~b}$ shows the SEM micrograph of autogenous WM, which reveals the presence of finer precipitates within austenitic grains and coarse precipitates within the $\delta$ ferrite. Chemical composition of the WM region determined by EDS is shown in Fig. 4c, where the composition of alloying elements in WM matches with the PM. In order to determine the type of precipitates available within $\delta$ ferrite, the sample was etched with Murakami's reagent near boiling point. Murakami's reagent preferentially etches the carbides at the austenite grain boundaries and $\delta$ ferrite. Micrograph of WM etched with Murakami's reagent is shown in Fig. 4d and it shows the intercellular segregation of alloying elements (grey phase). EDS line scan across the grey phase (L1) for elemental variation in $\mathrm{Cr}$ and $\mathrm{Ni}$ is presented in Fig. 4e. The marginal increase in $\mathrm{Cr}$ concentration and reduction in $\mathrm{Ni}$ concentration across the grey phase suggests the presence of $\delta$ ferrite. The composition of the 


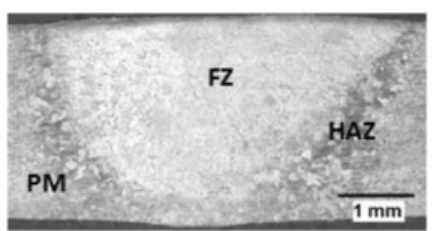

a. Macrograph
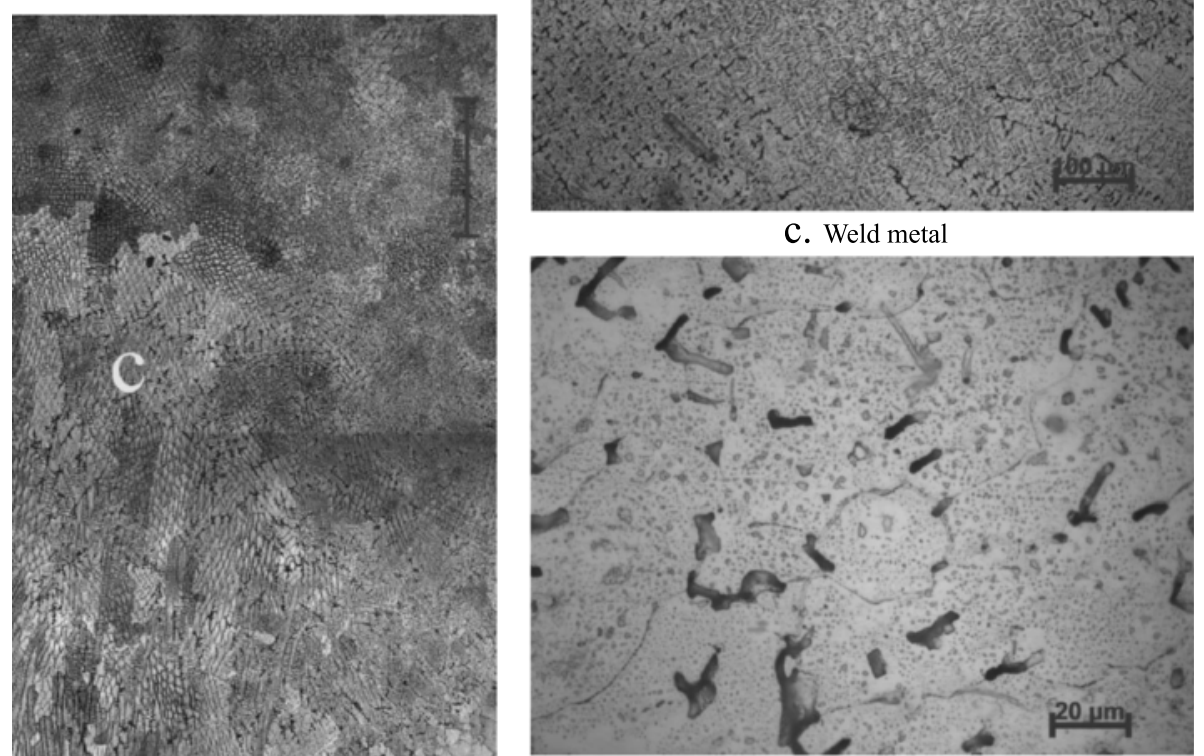

d. Weld metal at high magnification

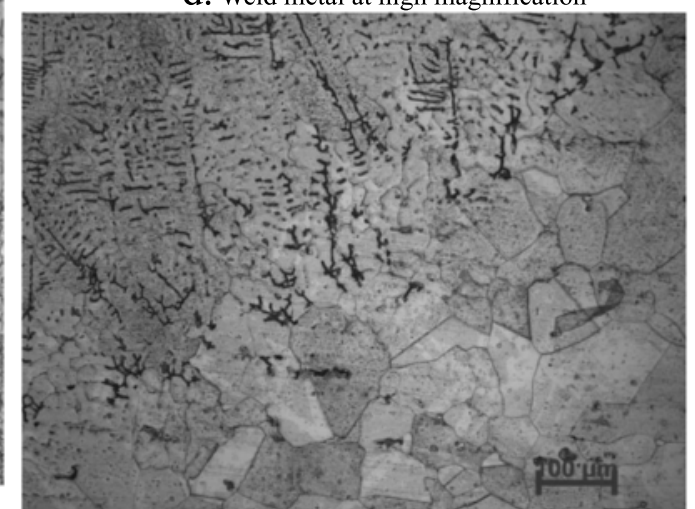

e. Fusion line

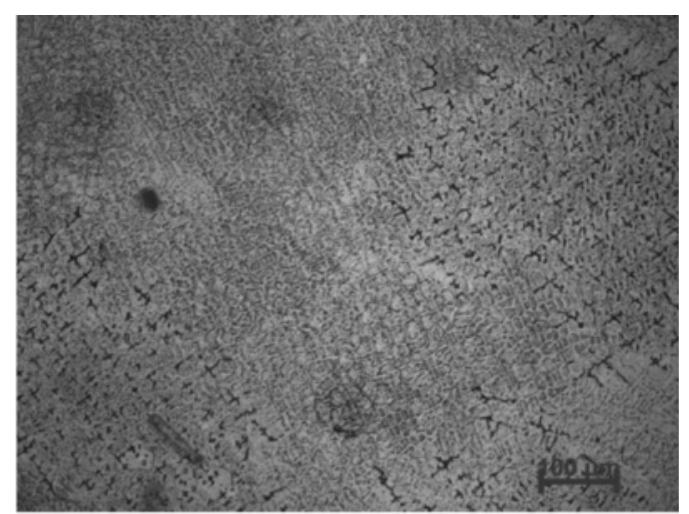

c. Weld metal

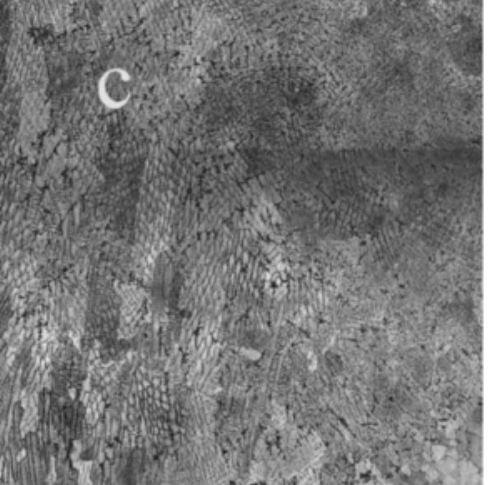

i.

ing $\mathrm{C}$

b. Micrograph across the weld

Fig. 2 Optical micrograph of autogenous GTA-welded joint. a Macrograph. b Micrograph across the weld. c Weld metal. d Weld metal at high magnification. e Fusion line

$\delta$ ferrite region was measured by EDS analysis on the spot (S1) and found to be rich in Fe, Cr, B and C.

SEM micrographs of the filler-added weld joint are shown in Fig. 5 and the WM micrograph shown in Fig. 5a reveals randomly oriented fully austenitic dendritic grains with no $\delta$ ferrite. The elemental spectrum of the WM region marked in Fig. 5a was determined by EDS and presented in Fig. 5b. The WM composition is similar to the composition of the filler metal added to the weld. The fusion line and HAZ of the filler-added weld joint, shown in
Fig. $5 \mathrm{c}$, reveals the columnar austenitic grains in the weld close to the fusion line with no $\delta$ ferrite and few coarse precipitates within the coarsened austenitic grains of the HAZ. The WM at higher magnification, shown in Fig. 5d, reveals the presence of interdendritic and grain boundary precipitates. The EDS elemental mapping of $\mathrm{Nb}, \mathrm{Mo}$ and $\mathrm{C}$ for the WM region marked in Fig. $5 \mathrm{~d}$ is shown in Fig. 5e, f, g, respectively. The precipitates are confirmed to be the rich in $\mathrm{Nb}, \mathrm{Mo}$ and $\mathrm{C}$; segregation of other alloying elements is not observed from the EDS analysis. 


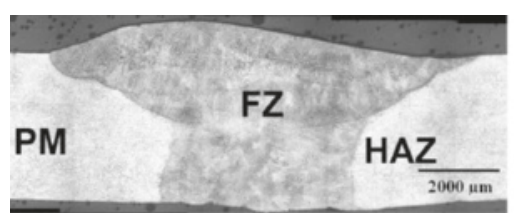

a. Macrograph
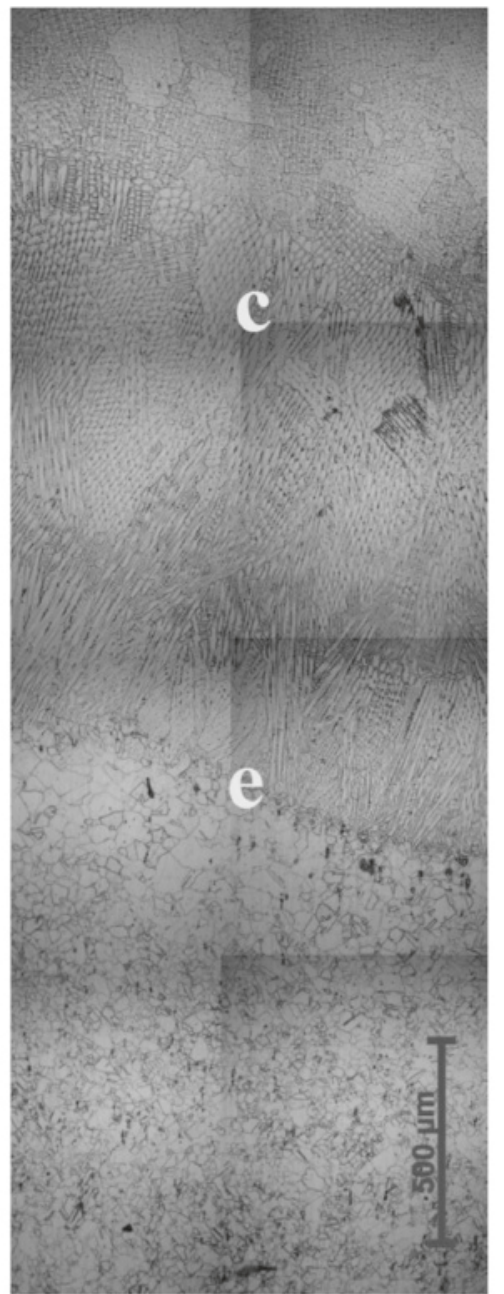

b. Micrographacross the joint

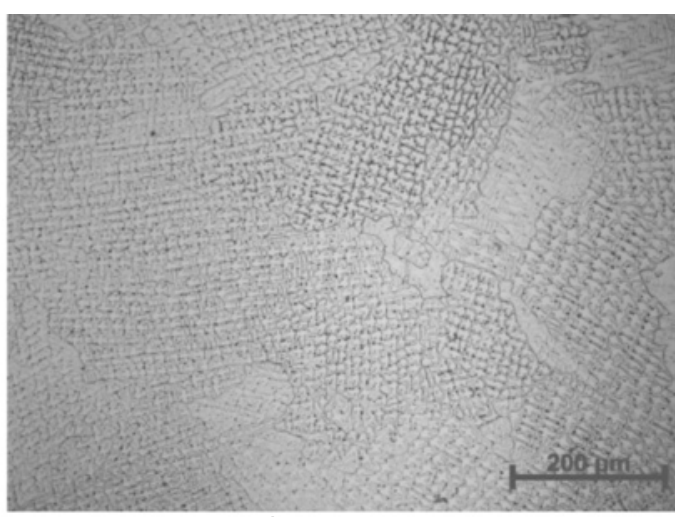

C. Weld metal

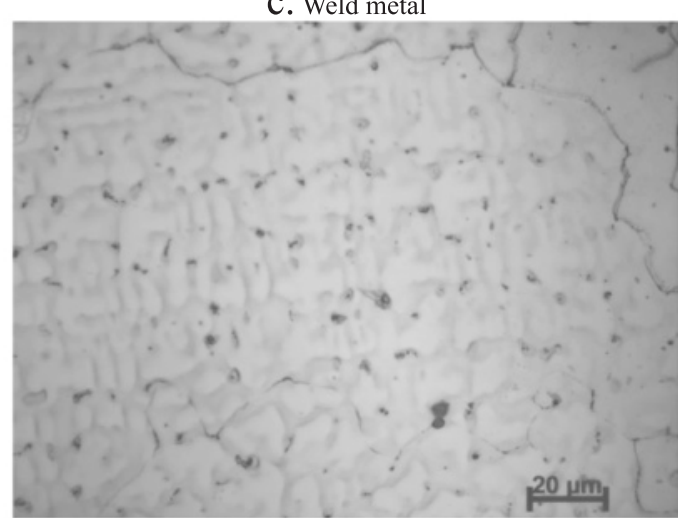

d. Weld metal at high mag.

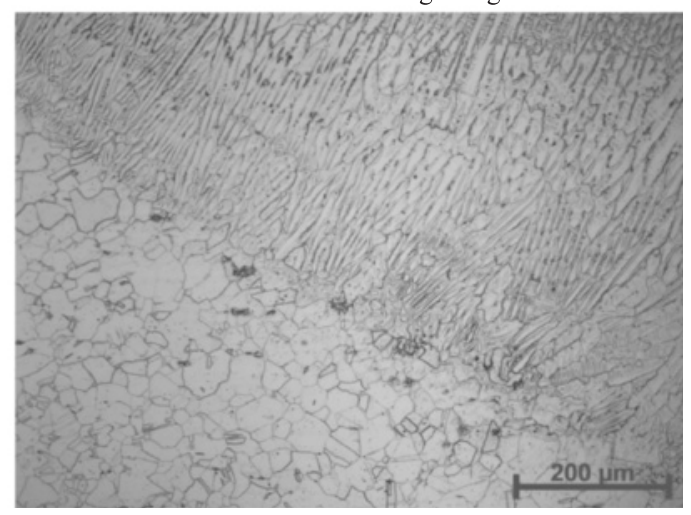

e. Fusion line

Fig. 3 Optical micrograph of filler-added GTA-welded joint. a Macrograph. b Micrograph across the joint. c Weld metal. d Weld metal at high magnification. e Fusion line

\section{Ferrite measurement}

The amount of $\delta$ ferrite in the WM of autogenous and filler-added weld joints was measured using ferritescope and presented in Table 4 . The average ferrite content of the autogenous WM is found to be $1.57 \%$ and no $\delta$ ferrite is found in the WM of filler-added joint. The amount of $\delta$ ferrite determined using the ferritescope for autogenous WM is much lower than volume of dark phase (termed as $\delta$ ferrite) in the microstructure. The amount of dark phase in autogenous weld is found to be $8.23 \%$ by image analysis.

\section{Tensile properties}

The engineering stress-strain curves of autogenous and filler-added weld joints at various test temperatures are shown in Fig. 6a, b, respectively, and the tensile properties are presented in Table 5. The RT tensile strength of autogenous weld joint is lesser than the PM strength ( $-2 \%)$, with failure located in the weld centre. In case of filler-added joint, the tensile strength exceeded the PM strength (+6\%), with failure in the parent material. The tensile strength of both autogenous and filler-added weld joints 


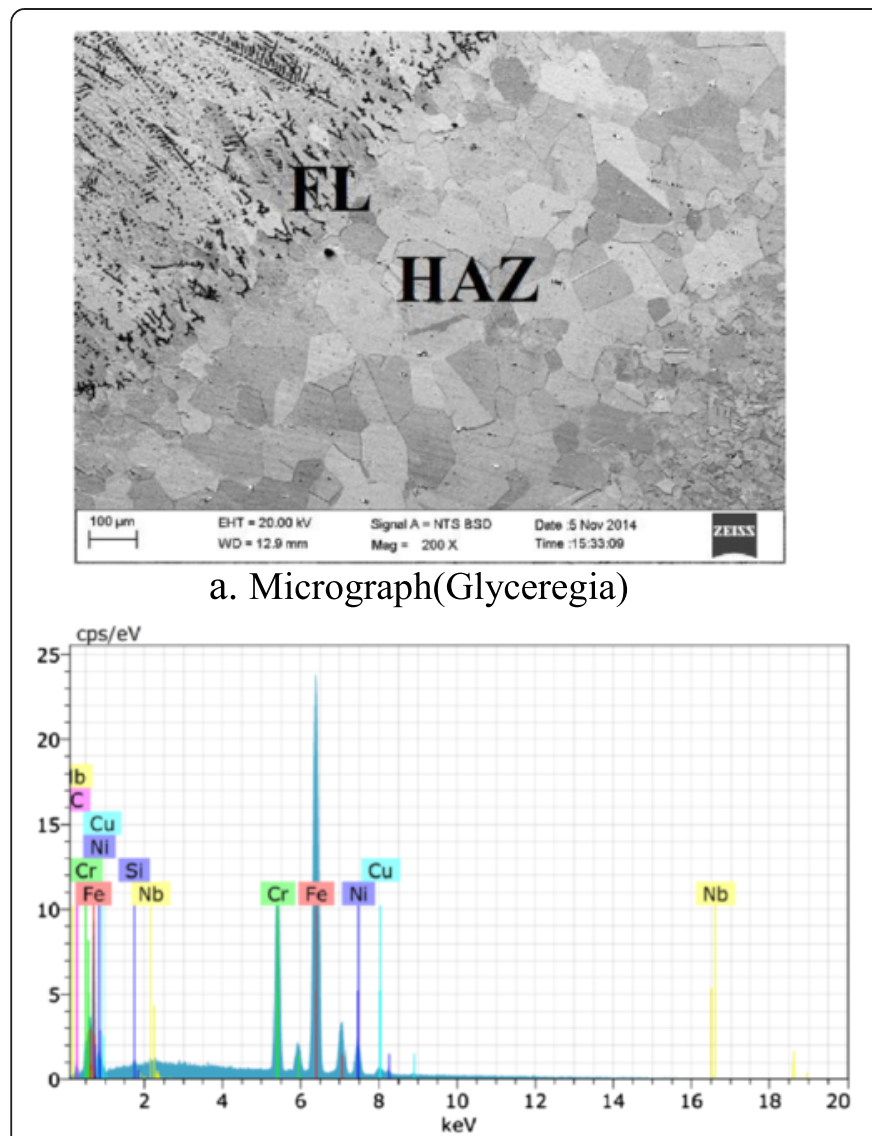

c. EDS composition of weld metal

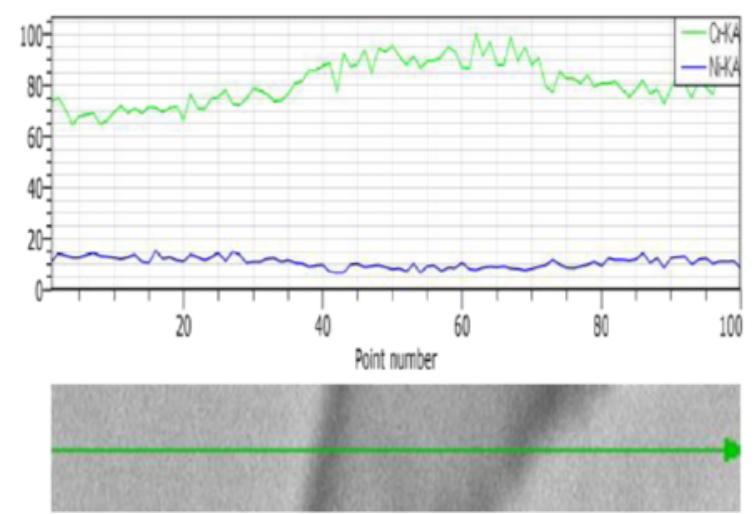

e. Line scan across grey phase (L1)

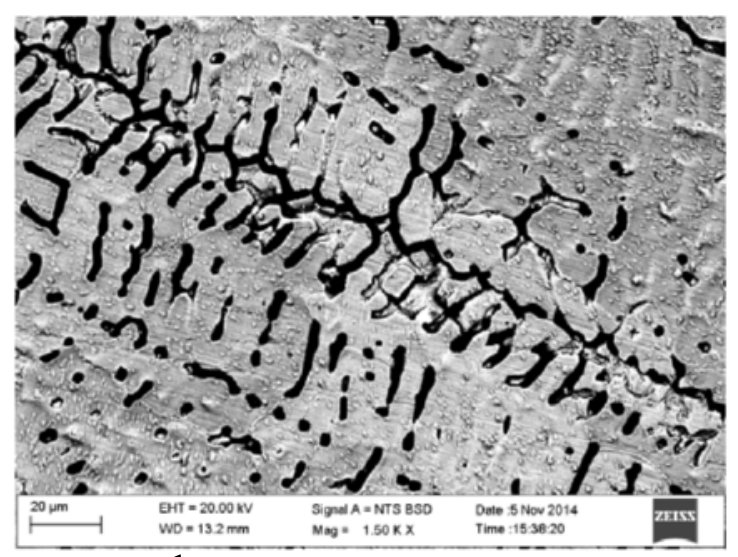

b. Weld metal (Glyceregia)

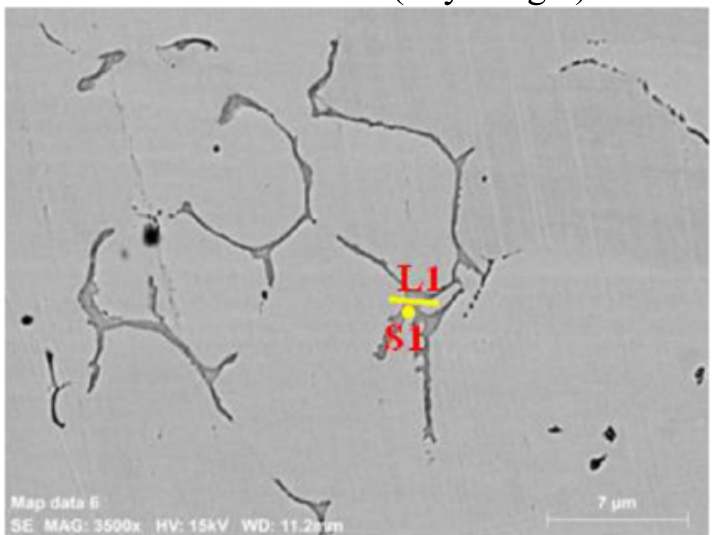

d. Weld metal (Murakamai’s)

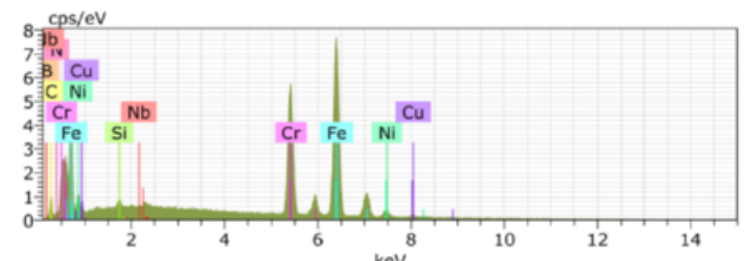

\begin{tabular}{|c|c|c|c|}
\hline Element & At \% & Element & At \% \\
\hline $\mathrm{Fe}$ & 38.15 & $\mathrm{~B}$ & 15.26 \\
\hline $\mathrm{Cr}$ & 16.82 & $\mathrm{Nb}$ & 0.08 \\
\hline $\mathrm{Ni}$ & 2.20 & $\mathrm{Si}$ & 0.55 \\
\hline $\mathrm{Cu}$ & 0.78 & $\mathrm{~N}, \mathrm{C}$ & $1.98,24.2$ \\
\hline
\end{tabular}

f. Spot EDS of grey phase

Fig. 4 SEM micrograph of Autogenous weld joint. a Micrograph (Glyceregia). b Weld metal (Glyceregia). c EDS composition of weld metal. d Weld metal (Murakami's). e Line scan across the grey phase (L1). $\mathbf{f}$ Spot EDS of grey phase

decreased with increase in test temperature. The tensile strength decreased by $31 \%$ in autogenous weld joints and by $36 \%$ in filler-added weld joint with increase in test temperature from RT to $650{ }^{\circ} \mathrm{C}$. The elongation of both the autogenous and filler weld joints decreased with increase in test temperature.

\section{Hardness}

The mid-thickness microhardness measured across the autogenous and filler-added weld joint are shown in Fig. 7. The WM of filler-added joint recorded higher hardness than the WM of autogenous joint; steep hardness variations were observed within the WM region of both autogenous and filler-added joints. The lowest hardness value 


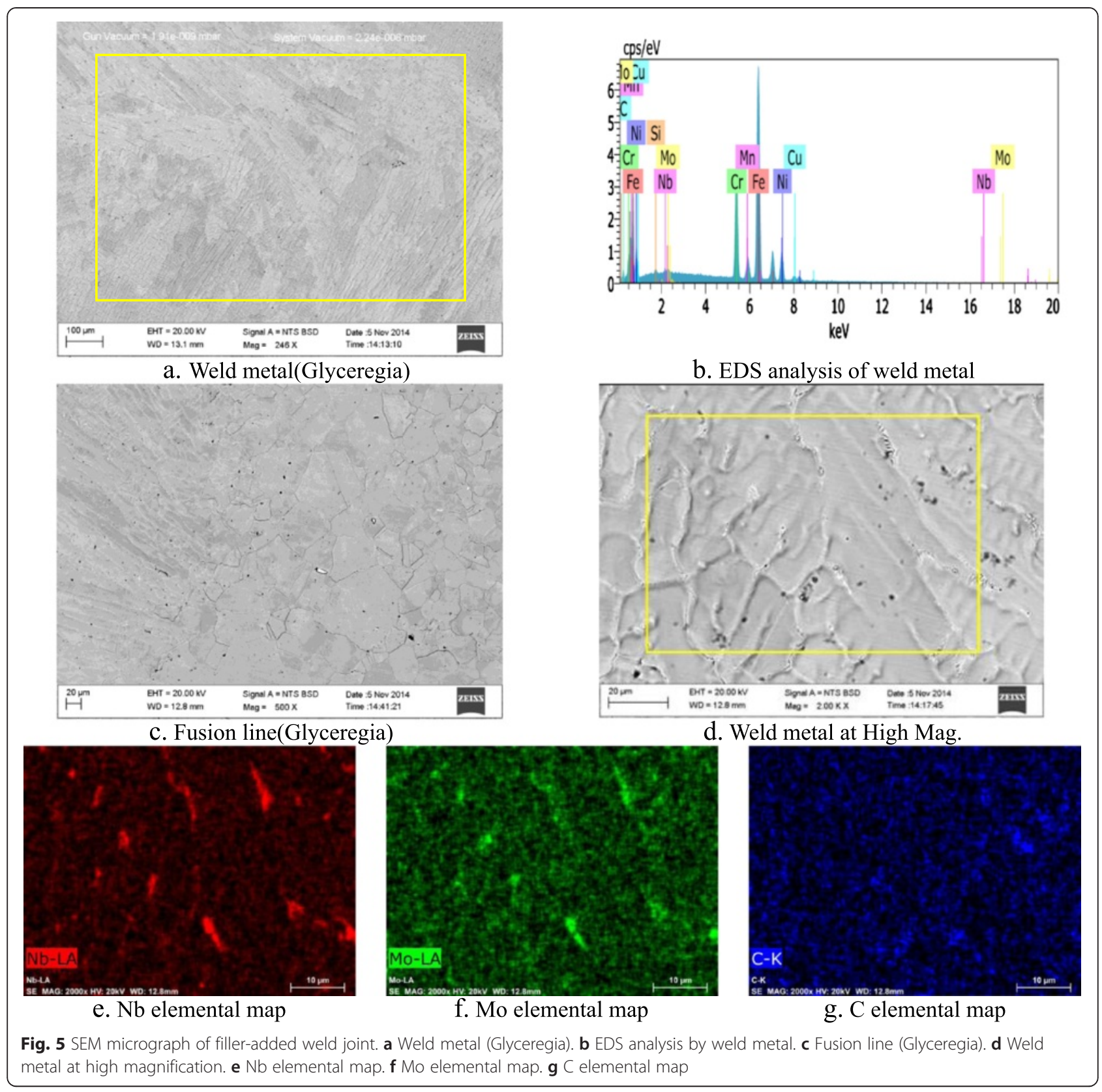

was recorded in the WM region close to the FL for both autogenous and filler-added joints. The HAZ region of both the autogenous and filler-added joints has not undergone softening due to the weld thermal cycles and retained its hardness equivalent to that of the PM (175 HV).

Table 4 Percentage of delta ferrite in welds of Super $304 \mathrm{H}$ joint

\begin{tabular}{llll}
\hline Joint & $\delta$ ferrite (\%) & $\begin{array}{l}\text { Average } \delta \\
\text { ferrite }(\%)\end{array}$ & $\begin{array}{l}\text { Standard } \\
\text { deviation (\%) }\end{array}$ \\
\hline Autogenous & $\begin{array}{l}1.5,1.7,1.6,1.7,1.5, \\
1.7,1.4,1.5,1.6,1.5\end{array}$ & 1.57 & 0.106 \\
Filler added & No traces & Nil & Nil \\
\hline
\end{tabular}

\section{Fracture surfaces}

The fracture surface of autogenous joint tensile tested at RT and $550{ }^{\circ} \mathrm{C}$ is shown in Fig. $8 \mathrm{a}, \mathrm{b}$, respectively. The reduction in cross-sectional area of the specimen tested at RT is higher (refer to Fig. 8a) than that of the specimen tested at $550{ }^{\circ} \mathrm{C}$. The high magnification SEM fractograph of autogenous joints tested at RT and $550{ }^{\circ} \mathrm{C}$ is shown in Fig. 8c, d and invariably consists of dimples. Since the fracture of the autogenous joints was located in the WM, the dimple sizes closely match with that of the dendrite size. The precipitates segregated along the grain boundaries (marked by arrow) assisted in crack initiation. 


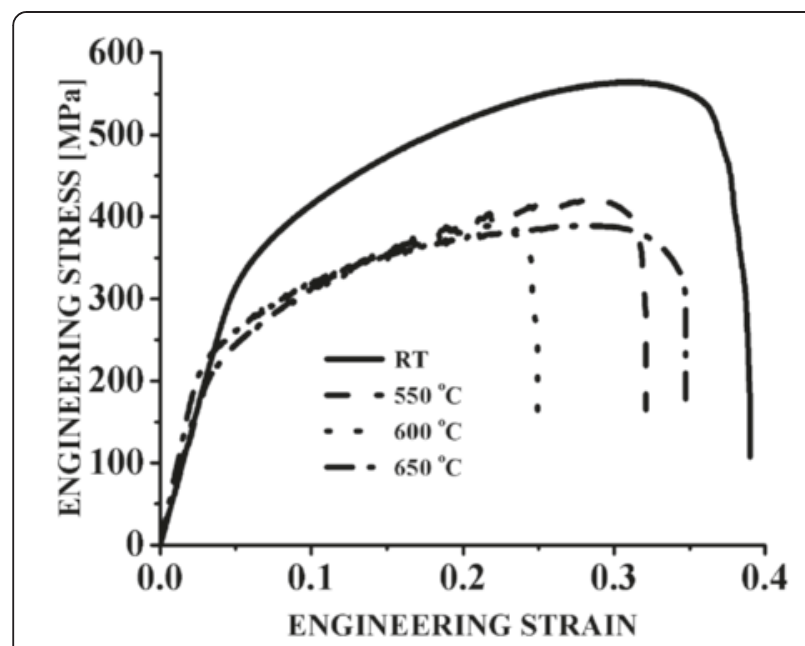

a. Autogenous weld joint

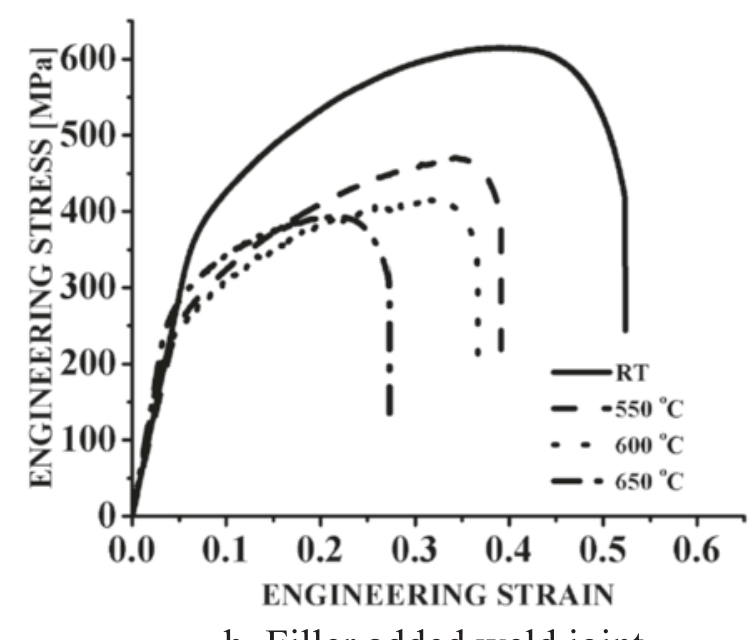

b. Filler added weld joint

Fig. 6 Engineering stress-strain curves of weld joints at various test temperatures. a Autogenous weld joint. b Filler-added weld joint

The SEM fractographs of filler-added joint tested at $\mathrm{RT}$ and $550{ }^{\circ} \mathrm{C}$ is shown in Fig. 8e, f, respectively, which reveals a similar behaviour with much lesser reduction in the cross-sectional area of the specimen tested at $550{ }^{\circ} \mathrm{C}$ than at RT. The fracture in the filler-added joints

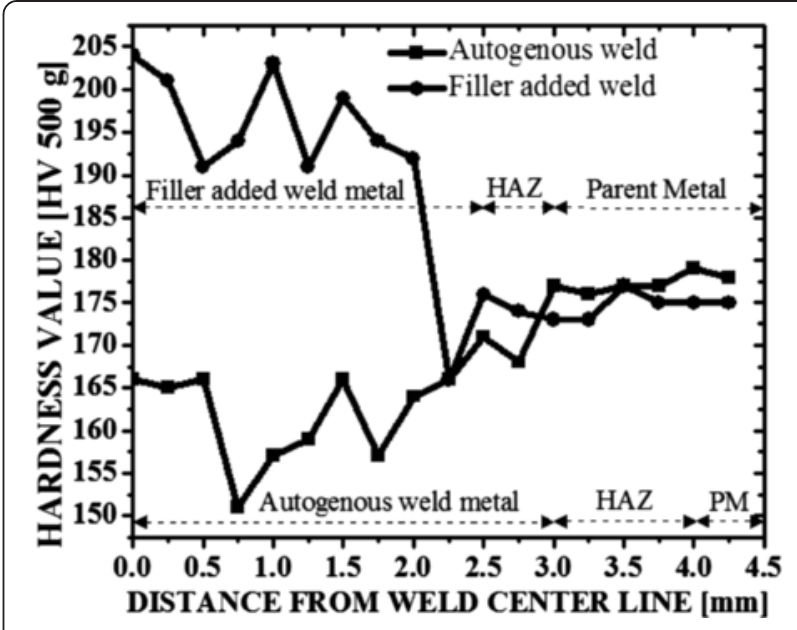

Fig. 7 Hardness profile across the weld centre line

was located at the PM, which is evident from the absence of dendritic structure in the high magnification fractographs shown in Fig. 8g, h. The specimen tested at $550{ }^{\circ} \mathrm{C}$ reveals coarse and fewer dimples than the specimen tested at RT (refer to Fig. 8g). Flat featureless regions which are much prominent in specimen tested at $550{ }^{\circ} \mathrm{C}$ evidence the reduction in elongation of the joint at high temperatures. The Nb-rich precipitates (marked by arrow) associated with the voids in the fracture surface of RT specimen act as the crack initiation site.

\section{Discussion}

The mode of solidification in stainless steels is strongly dependent on the chemical composition which is usually represented as $\mathrm{Cr}$ and $\mathrm{Ni}$ equivalents (Valiente Bermejo 2012; Brooks et al. 1983). The WRC-1992 constitution diagram $\mathrm{Cr} / \mathrm{Ni}$ equivalents are commonly used to predict the solidification mode and ferrite content of the weld based on composition of the alloy (Srinivasan et al. 2012). The $\mathrm{Cr}$ and $\mathrm{Ni}$ equivalent of autogenous weld metal is determined as 18.2 and $14.7 \%$, respectively. Similarly, the $\mathrm{Cr}$ and $\mathrm{Ni}$ equivalent for filler-added weld metal is determined as 19.4 and $23.1 \%$. The welds of

Table $\mathbf{5}$ Tensile properties of autogenous and filler-added weld joints of Super $304 \mathrm{H}$

\begin{tabular}{|c|c|c|c|c|c|}
\hline & $\begin{array}{l}\text { Test temperature } \\
\left({ }^{\circ} \mathrm{C}\right)\end{array}$ & $\begin{array}{l}0.2 \% \text { yield } \\
\text { strength (MPa) }\end{array}$ & $\begin{array}{l}\text { Ultimate tensile } \\
\text { strength (MPa) }\end{array}$ & $\begin{array}{l}\text { Elongation in } 25 \mathrm{~mm} \\
\text { gauge length (\%) }\end{array}$ & $\begin{array}{l}\text { Failure } \\
\text { location }\end{array}$ \\
\hline \multirow[t]{4}{*}{ Autogenous joint } & RT & $302.4 \pm 5.5$ & $564.3 \pm 7.0$ & $38.96 \pm 2.0$ & WM \\
\hline & 550 & $201.6 \pm 7.4$ & $420.4 \pm 10.0$ & $32.09 \pm 2.6$ & WM \\
\hline & 600 & $173.0 \pm 7.4$ & $388.2 \pm 7.6$ & $24.97 \pm 3.0$ & WM \\
\hline & 650 & $206.2 \pm 5.3$ & $389.0 \pm 8.5$ & $34.70 \pm 2.5$ & WM \\
\hline \multirow[t]{4}{*}{ Filler-added joint } & RT & $349.6 \pm 10.2$ & $614.6 \pm 11.7$ & $52.3 \pm 3.0$ & PM \\
\hline & 550 & $247.3 \pm 10.6$ & $470.2 \pm 10.7$ & $39.2 \pm 3.0$ & PM \\
\hline & 600 & $196.3 \pm 6.7$ & $413.6 \pm 12.5$ & $36.6 \pm 2.3$ & PM \\
\hline & 650 & $240.8 \pm 7.6$ & $392.7 \pm 13.7$ & $27.3 \pm 2.6$ & PM \\
\hline
\end{tabular}




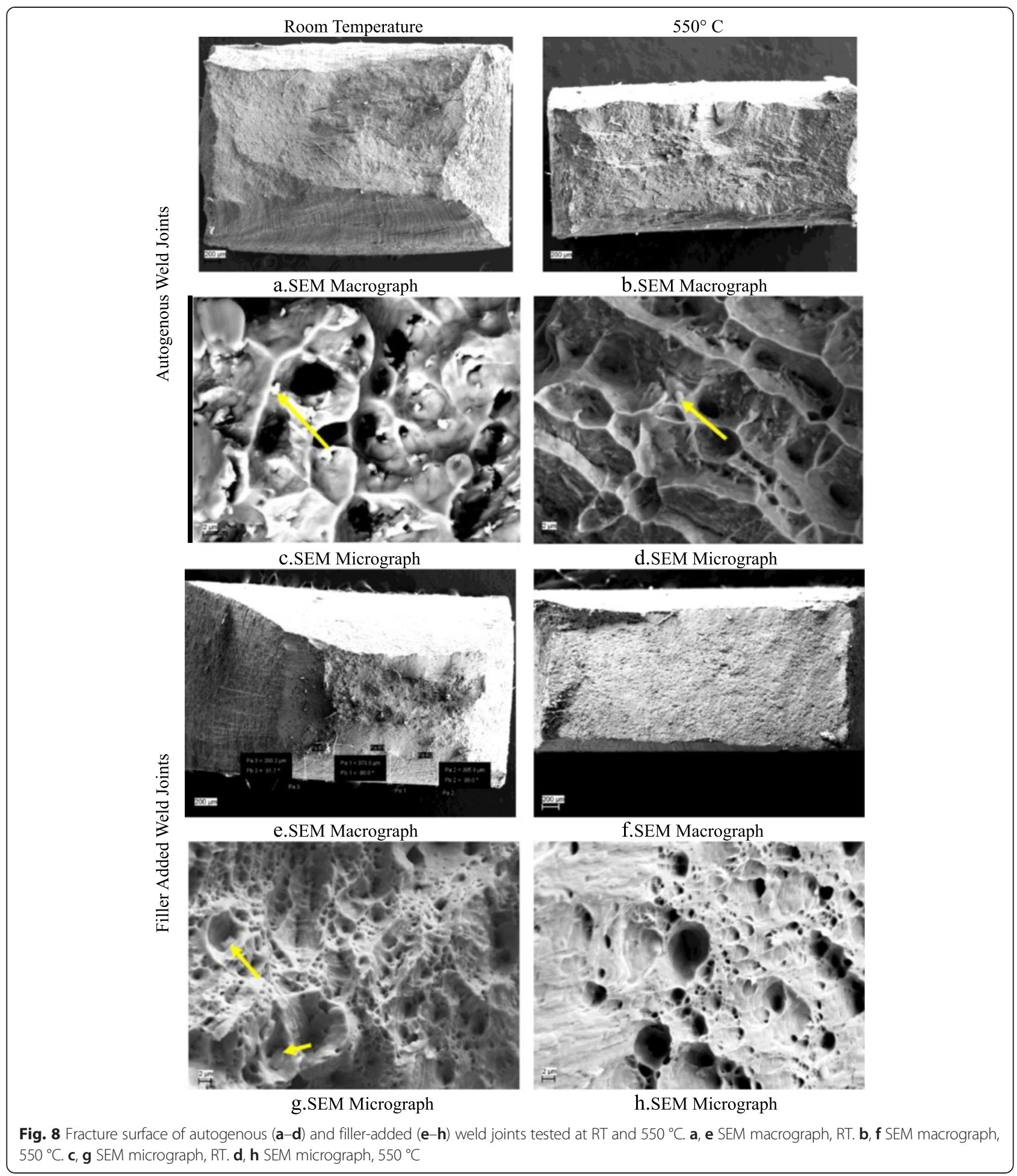

both autogenous and filler-added joints are predicted to solidify as primary austenite (A-mode) with no $\delta$ ferrite in the WM (as per WRC-1992 diagram). The WM of autogenous weld consists of $1.57 \% \delta$ ferrite (refer to Table 4), which is in contrary to the predicted weld metal microstructure.
The autogenous weld solidifies by epitaxial growth and a plane front solidification zone near the fusion line (refer to Fig. 2d) and transforms to cellular mode with microsegregation to the cellular boundaries (refer to Fig. 2b) (Elmer et al. 1989). The vertical section of the Fe-Ni-Cr ternary diagram is shown in Fig. 9 with lines 


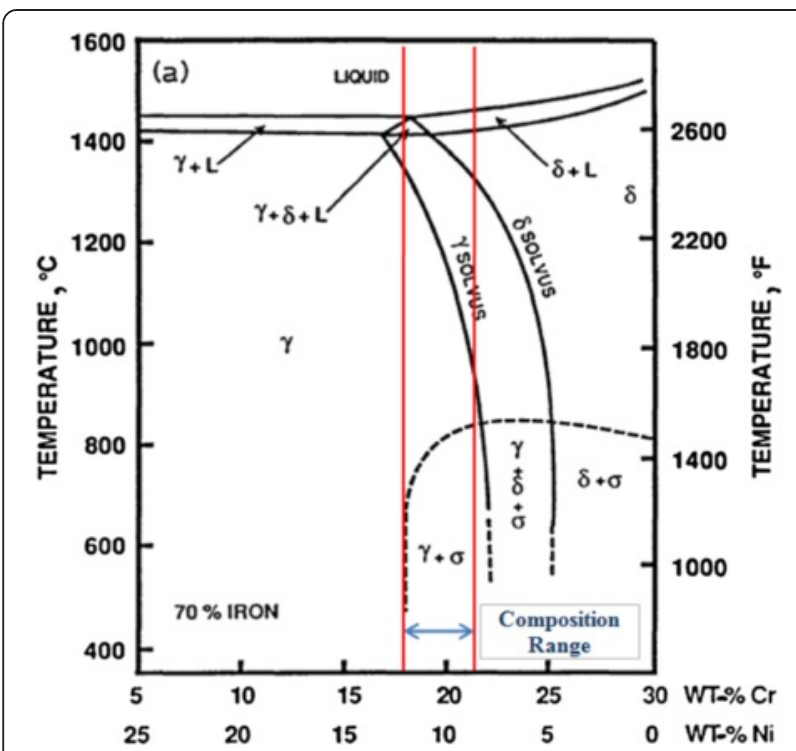

Fig. 9 Vertical section of Fe-Ni-Cr ternary diagram at $70 \%$ Fe content (Brooks et al. 1983)

representing the compositional range of the Super 304H. The first solidifying structure in the weld depends on the side in which the eutectic liquidus nominal composition lies and the remaining liquid may solidify as eutectic or peritectic based on the level of segregation (Brooks and Thompson 1991).

The autogenous weld of Super $304 \mathrm{H}$ first solidifies as $\delta$ ferrite near the fusion line due to the peritectic solidification, followed by eutectic single austenite solidification phase evident from the cellular structure of austenite in the weld centre. The austenite continues to grow into the peritectic $\delta$ ferrite by solid state transformation, with austenite as the more stable phase. Metalographically hard to distinguish peritectic and eutectic ferrite was retained in the intercellular austenitic/ austenitic and austenitic/ $\delta$-ferrite boundaries of the autogenous weld (refer to Fig. $2 \mathrm{~b}$ ), as the solid state transformation of $\delta$ ferrite to austenite is not complete due to segregation or cooling conditions (Brooks et al. 1983). The addition of $\mathrm{B}$ to stainless steel enhances the hardenability and creep strength, however the B in solid solution is beneficial and precipitated borides are detrimental. The segregation of $\mathrm{Fe}, \mathrm{Cr}, \mathrm{B}$ and $\mathrm{C}$ (refer to Fig. $4 \mathrm{f})$ in the intercellular region of the austenite reveals the presence of $(\mathrm{Fe}, \mathrm{Cr})_{23}(\mathrm{C}, \mathrm{B})_{6}$ borocarbides (Hoffman and ASM 1989; Karlsson et al. 1982). The limited solubility of B in austenitic stainless steel of 30 PPM at $900{ }^{\circ} \mathrm{C}$ may cause the excess $\mathrm{B}$ to segregate along the grain boundaries and combine with $\mathrm{Cr}$ and Fe to form a low melting eutectic with the austenite (Carinci 1994). Such eutectic formation and borocarbide precipitation within the ferrite stringers alter the composition of the solidifying liquid ahead of the austenite/liquid interface and hinder the liquid to solidify as austenite in the intercellular boundaries.

In case of filler-added weld, the WM is fully austenitic with no $\delta$ ferrite as predicted (refer to Fig. 5a) and it is attributed to the increased addition of $\mathrm{Ni}$, $\mathrm{Nb}$, Mo and $\mathrm{N}$ to the weld metal. The higher $\mathrm{Ni}$ equivalent of filler-added WM resulted in A mode of solidification with primary austenite dendrites as single phase (refer to Fig. 5d) (Bonollo et al. 2004). The precipitation of $(\mathrm{Fe}, \mathrm{Cr})_{23}(\mathrm{C}, \mathrm{B})_{6}$ was to be suppressed by the Mo, $\mathrm{Nb}$ and $\mathrm{N}$ addition to the $\mathrm{WM}$ of filleradded joint. The formation of $(\mathrm{Nb}, \mathrm{Mo}) \mathrm{C}$ clusters or (Nb,Mo) carbonitrides (refer to Fig. 5e, f, g) prevents the supplement of $\mathrm{C}$ to the grain boundaries and retards the formation of detrimental carboborides in filler-added joint (Hara et al. 2004).

The failure of the autogenous weld joint was located at the weld centre regardless of the test temperature, recorded the lowest hardness in the weld joint (refer to Fig. 7). In single pass autogenous weld, the weld metal solidifies as coarse columnar grains by epitaxial growth towards the weld centre with preferential orientation, which may result in a weak centre line in the weld (Villafuerte and Kerr 1990). The higher tensile strength of filler-added joint than the autogenous joint at all test temperatures is attributed to the fine $\mathrm{Nb}$ - and Mo-rich carbides. In turn, B retained in the austenitic matrix without precipitation of detrimental carboborides in the WM of filler-added joint. The retention of elemental B in the WM increases the hardenability and thereby resulted in increased strength of the filler-added joint. The reduction in the strength values of weld joints with increase in test temperature is attributed to the accelerated recovery process (Choudhary and Rao Palaparti 2012).

\section{Conclusions}

1. Autogenously welded GTAW joints of Super 304H austenitic stainless steel resulted in weld metal with austenite and $\delta$ ferrite $(1.57 \%)$. Boron tends to segregate along the intercellular boundaries to form $(\mathrm{Fe}, \mathrm{Cr})_{23}(\mathrm{C}, \mathrm{B})_{6}$ borocarbides.

2. In the filler-added GTAW joints, the increased Mo, $\mathrm{Nb}$ and $\mathrm{N}$ content suppressed the precipitation of coarse borocarbides by formation of $(\mathrm{Nb}, \mathrm{Mo}) \mathrm{C}$ clusters or $(\mathrm{Nb}, \mathrm{Mo})$ carbonitrides and retained elemental $\mathrm{B}$ within the matrix to increase the hardenability of the joint.

3. Autogenous GTAW joints exhibited inferior room temperature and high temperature tensile strength compared to filler-added GTAW joints with increased austenite formers $(\mathrm{Ni})$ and carbide formers $(\mathrm{Nb}$ and $\mathrm{Mo})$. 


\section{Competing interests}

The authors declare that they have no competing interests.

\section{Authors' contributions}

All authors read and approved the final manuscript.

\section{Acknowledgements}

The authors wish to express their sincere thanks to M/s Mailam India Ltd, Pondicherry, India for providing financial assistance to carry out this research work through the Mailam India Research (MIR) Fellowship, M/s Salzgitter Mannesmann Stainless Tubes Italia Srl of Italy for supplying the Super 304H tubes required to carry out this work and The Director, Naval Materials Research Laboratory, Ambernath, Mumbai for providing the facility to carry out hot tensile testing.

\section{Author details}

${ }^{1}$ Center for Materials Joining and Research (CEMAJOR), Department of Manufacturing Engineering, Annamalai University, Annamalai Nagar, Tamil Nadu 608002, India. ${ }^{2}$ Naval Materials Research Laboratory (NMRL), Ambernath, Mumbai 421506, India.

Received: 12 June 2015 Accepted: 9 November 2015

Published online: 14 November 2015

\section{References}

Bai, J. W., Liu, P. P., Zhu, Y. M., et al. (2013). Coherent precipitation of copper in Super 304H austenite steel. J Mater Sci Eng A, 584, 57-62.

Bonollo, F., Tiziani, A., Tovo, R., et al. (2004). Superaustenitic stainless steels: the microstructure and fatigue strength of welded joints. J Weld Int, 18, 24-30.

Brooks, J. A., \& Thompson, A. W. (1991). Microstructural development and solidification cracking susceptibility of austenitic stainless steel welds. J Int Mater Rev, 36, 16-44.

Brooks, J. A., West, A. J., \& Thompson, A. W. (1983a). Effect of weld composition and microstructure on hydrogen assisted fracture of austenitic stainless steels. J Metall Trans A, 14, 75-84

Brooks, J. A., Williams, J. C., \& Thompson, A. W. (1983b). Microstructural origin of the skeletal ferrite morphology of austenitic stainless steel welds. J Metall Trans A, 14A, 1271-1281.

Brozda, J. (2007). New generation austenitic steels used in supercritical power industry plant. J Welding International, 21, 512-520.

Carinci, G. M. (1994). Grain boundary segregation of boron in an austenitic stainless steel. J App/ Surf Sci, 76, 266-271.

Choudhary, B. K., \& Rao Palaparti, D. P. (2012). Comparative tensile flow and work hardening behaviour of thin section and forged thick section $9 \mathrm{Cr}-1 \mathrm{Mo}$ ferritic steel in the framework of voce equation and Kocks-Mecking approach. Journal of Nuclear Materials, 430, 72-81.

Darja Steiner, P., Grega, K., Miran, P., et al. (2011). Differential scanning calorimetry study of the solidification sequence of austenitic stainless steel. Journal of Thermal Analysis and Calorimetry, 105, 251-257.

David, S. A., Siefert, J. A., \& Feng, Z. (2013). Welding and weldability of candidate ferritic alloys for future advanced ultrasupercritical fossil power plants. J Sci Technol Weld Joining, 18, 632-651.

Elmer, J. W., Allen, S. M., \& Eagar, T. W. (1989). Microstructural development during solidification of stainless steel alloys. J Metall Trans A, 20, 2117-2131.

Ha, V. T., \& Jung, W. S. (2012). Creep behavior and microstructure evolution at $750^{\circ} \mathrm{C}$ in a new precipitation strengthened heat resistant austenitic stainless steel. J Mater Sci Eng A, 558, 103-111.

Hara, T., Asahi, H., Uemori, R., et al. (2004). Role of combined addition of niobium and boron and of molybdenum and boron on hardnenability in low carbon steels. J ISIJ Int, 44, 1431-1440.

Hoffman, J. P., \& ASM, D. j. (1989). The distribution of boron in stainless steels as revealed by a nuclear technique. J $S$ Afr Inst Min Metal, 89, 81-87.

Hunter, A., \& Ferry, M. (2002). Phase formation during solidification of AISI 304 austenitic stainless steel. J Scripta Mater, 46, 253-258.

Indrani, S., Amankwah, E., Kumar, N. S., et al. (2011). Microstructure and mechanical properties of annealed SUS $304 \mathrm{H}$ austenitic stainless steel with copper. J Mater Sci Eng A, 528, 4491-4499.

Karlsson, L., Andren, H. O., \& Nord, H. (1982). Grain boundary segregation in an austenitic stainless steel containing boron - an atom probe study. J Scripta Metallurgica, 16, 297-302.
Kim, M. Y., Kwak, S. C., Choi, I. S., et al. (2014). High-temperature tensile and creep deformation of cross-weld specimens of weld joint between T92 martensitic and Super304H austenitic steels. J Mater Character, 97, 161-168.

Li, X. M., Zou, Y., Zhang, Z. W., \& Zou, Z. D. (2010). Microstructure evolution of a novel Super304H steel aged at high temperatures. J Mater Trans, 51, 305-309.

Shu Ping, T., Zhen Hua, W., Shi Chang, C., et al. (2010). Hot deformation behavior of Super304H austenitic heat resistant steel. J Miner Metall Mater, 17, 167-172.

Srinivasan, G., Bhaduri, A. K., Albert, S. K., et al. (2012). Effect of phosphorous and silicon on hot cracking susceptibility of $14 \mathrm{Cr}-15 \mathrm{Ni}-2.3 \mathrm{Mo}$ Ti-modified fully austenitic stainless steel. J Weld World, 56, 2-13.

Thomas, B. G. (2013). Recent Advances in Steels for Coal Fired Power Plant: A Review. J Trans Indian Inst Met, 66, 631-640.

Valiente Bermejo, M. A. (2012). Henry Granjon Prize Competition 2012 Winner Category B: Materials Behaviour and Weldability Influence of the [Creq + Nieq] alloy level on the transition between solidification modes in austenitic stainless steel weld metal. J Weld World, 56, 2-14.

Vekeman, J., Huysmans, S., \& De Bruycker, E. (2014). Weldability assessment and high temperature properties of advanced creep resisting austenitic steel DMV304HCu. J Weld World, 58, 873-882.

Villafuerte, J. C., \& Kerr, H. W. (1990). Grain structures in gas tungsten-arc welds of austenitic stainless steels with ferrite primary phase. J Metall Trans A, 21, 979-986.

Viswanathan, R., Henry, J. F., Tanzosh, J., et al. (2005). U.S. program on materials technology for ultra-supercritical coal power plants. Journal of Materials Engineering and Performance, 14, 281-292.

Yang, H., Peng, F., Miao, X., et al. (2006). Investigation of the aging behavior on boiler steel tube Super304H. J Press Equip Syst, 4, 96-99.

\section{Submit your manuscript to a SpringerOpen ${ }^{\circ}$ journal and benefit from:}

- Convenient online submission

Rigorous peer review

- Immediate publication on acceptance

- Open access: articles freely available online

- High visibility within the field

- Retaining the copyright to your article

Submit your next manuscript at $>$ springeropen.com 